\title{
Subsídios teóricos e críticos para a historiografia da literatura brasileira do século XXI
}

Pesquisas recentes de acento historiográfico sobre literatura brasileira sinalizam descentralizações e desestabilizações de espaços canônicos no campo literário do Brasil, colocando a pergunta sobre a validade e a plausibilidade de conceitos até então utilizados para balizar e legitimar o campo literário. Possibilidades interseccionais de agenciamento de categorias de gênero, classe e raça, aliadas à perspectivação radical oferecida pelo revigoramento de ênfases antropológicas, têm apontado para novas formas de protagonismo que abalam não apenas estética, política, social e geograficamente os espaços ocupados pelo fenômeno literário, mas também sua própria relação com a esfera do (não) humano. Em razão disso, pode-se perguntar: de que maneira essas novas orientações implicam outras formas de escrever histórias da literatura?

Deste número fazem parte duas seções. Em "Artigos", pesquisadores brasileiros e estrangeiros contemplam a diversidade da cena literária contemporânea, problematizando aspectos teóricos e críticos capazes de subsidiar a pesquisa acadêmica no campo da historiografia da literatura brasileira do século XXI.

No ensaio "Hoje em dia, Machado de Assis seria blogueiro", Dau Bastos, da Universidade Federal do Rio de Janeiro, busca refazer o percurso empreendido pela literatura brasileira desde a década de 1840 até a atualidade, com vistas a "levantar a irônica hipótese de a poesia encontrar no computador a possibilidade de recuperar o espaço e o prestígio de que usufruía antes da consolidação do romance nos trópicos". A ênfase recai sobre autores marcantes do período, especialmente Machado de Assis, autor que praticou diferentes gêneros literários.

Em "Por uma epistemologia da sexualidade na literatura contemporânea", Claudicélio Rodrigues da Silva, da Universidade Federal do Ceará, apresenta o esboço de uma epistemologia da sexualidade aplicada aos estudos da literatura contemporânea, tendo como pressupostos teóricos dois conceitos de Foucault: episteme e dispositivo. Nessa perspectiva, avalia os seguintes conceitos carregados de tensões discursivas e políticas: interseccionalidade, masculinidade/virilidade, feminino, identidades de gênero, queer, performatividade e heteronormatividade compulsória. 
No artigo "Vias tortas, papo reto: a centralidade da literatura da favela", Gundo Rial y Costas e Ligia Chiappini, da Freie Universität Berlin, abordam a paradigmática Festa Literária das Periferias (FLUP) do Rio de Janeiro e a sua prolífica produção de novos autores, incluindo material empírico próprio, baseado numa etnografia multisituada de nove anos da festa com os dois leitmotivs: o "abraço coletivo" e o "papo reto". Assim, contempla-se o papel dos mediadores culturais, ao indagar pela centralidade da literatura da favela, apresentando, analisando e destacando seus valores.

Em "Historiografia literária brasileira hoje: hibridismo e multiplicidade", Helena Bonito Couto Pereira procura elencar componentes para empreender uma discussão sobre a escrita de uma possível historiografia literária no século XXI. Para tal, a autora empreende uma revisão dos momentos principais da historiografia desde os precursores no século XIX, até a recente História da literatura brasileira (2011), de Carlos Nejar, propondo "a retomada e a complementação das tendências da produção recente, tais como o hibridismo, a multiplicidade e a heterogeneidade, em suas relações de continuidade ou ruptura com a produção do século passado".

Em "As porosidades do campo literário nacional: a emergência da literatura pós-Holocausto no Brasil”, Joanna M. Moszczynska, da Universität Regensburg, contextualiza a literatura brasileira pós-Holocausto como um conjunto literário autônomo e heterogêneo que irrompe as fronteiras entre as noções da literatura brasileira, da literatura judaica e da literatura do Holocausto. Assim, provoca uma reflexão acerca de novas maneiras de rememoração no Brasil pós-ditatorial.

João Claudio Arendt, da Universidade Federal do Mato Grosso do Sul, em “'De tudo, à polenta ficarei atento': notas sobre a obra do escritor cocanhês Joanim Pepperoni, PhD", sistematiza e discute a técnica de escrita e os principais temas presentes na produção literária do escritor da Serra Gaúcha. A abordagem foca, inicialmente, na recriação, pelo escritor, do mito medieval da Terra da Cocanha e sua atualização ao contexto cultural da região de imigração italiana no Rio Grande do Sul; em seguida, avalia a paródia como técnica de escrita preferida pelo autor para criticar comportamentos e instituições locais e nacionais; e, por fim, aborda o olhar detrator do bardo cocanhês sobre o sistema literário em que está situado.

Em "Narrativas do esgotamento e historiografia (literária) brasileira no Antropoceno", Mariana Simoni, da Freie Universität Berlin, parte da entronização do conceito de Antropoceno nos discursos das ciências humanas e vincula o novo 
impulso narrativo gerado pela consciência tanto do impacto destrutivo da ação humana sobre o planeta Terra, quanto pela ameaça de esgotamento dos recursos naturais, à emergência de narrativas do esgotamento comprometidas com práticas situadas de resistência. $\mathrm{O}$ objetivo do texto é enfatizar o aspecto performativo neste novo gesto de narrar, que invariavelmente implica reescrituras da história literária brasileira a partir de perspectivas mais além do humano.

Em "Como o código bibliográfico ajuda a reconhecer a importância das materialidades dos textos", Priscila Oliveira Monteiro Moreira, da Universidade de Coimbra, argumenta a favor da importância do conceito de "código bibliográfico" para os Estudos Literários contemporâneos, oferecendo uma perspectiva crítica em direção a um materialismo hermenêutico capaz de abarcar noções mais amplas sobre texto, o que inclui também a condição material daquilo que, em qualquer suporte, pode ser interpretado.

Em "Rastros da Shoah na recente literatura brasileira", Marcelo Ferraz de Paula, da Universidade Federal de Goiás, discute a presença da Shoah em obras recentes da literatura brasileira, buscando compreender aspectos formais e éticos relacionados à investida artística neste tema. $\mathrm{O}$ diálogo teórico-crítico principal é com o ensaio "Literatura da Shoah no Brasil", de Márcio Seligmann-Silva (2007), e as reflexões são realizadas com base no exame de $O$ que os cegos estão sonhando?, de Noemi Jaffe, K. Relato de uma busca, de Bernardo Kucinski, e O irmão alemão, de Chico Buarque.

Em "El país que no existió: tiempo y narración en O Brasil é bom, de André Sant'Anna", Rodrigo Gomes de Araujo, da Universidad Autonoma Metropolitana Azcapotzalco, analisa como André Sant'Anna critica a conjuntura política, ao mesmo tempo em que realiza uma projeção distinta de seu país. Nessa discussão, a temporalidade é o elemento que confere profundidade histórica e política ao livro em foco.

O artigo "Escrita não criativa e neuro-estética: conceitos, aspectos, possibilidades", de Sergio Marcone Santos, da Universidade Federal do Paraná, apresenta conceitos da neurociência, em particular os que se detêm sobre a relação mente, corpo e estética - a neuro-estética. Nessa perspectiva, analisa as obras Traffic (2007), Trânsito (2016) e HILLARY: The Hillary Clinton emails (2019), de Kenneth Goldsmith. 
Em "A hora da aula e o tempo da história nos estudos literários", Eduardo Jorge de Oliveira, da Universidade de Zurique, conversa com Eduardo Sterzi, da Unicamp, sobre alguns aspectos da aula de literatura e do tempo da história literária. Os autores conectam a literatura, seus saberes diretos e indiretos, relações de força entre história e historiografia literária além da aula de literatura como um acontecimento único, uma força além do conteúdo ou das técnicas pedagógicas de ensino.

Em "Diálogo inimaginável sobre a catástrofe brasileira: sátira literária", colocamos frente a frente o escritor Ricardo Lísias, o editor Gabriel Nascimento e dois escritores que publicam suas obras sob pseudônimo: Messias Botnaro e Joanim Pepperoni, PhD. O resultado é um texto que embaralha as fronteiras entre ficção e realidade, assumindo contornos satíricos.

Completando o tema do dossiê, na seção Resenhas, Pedro Barbosa Rudge Furtado, da Universidade Estadual Paulista Júlio de Mesquita Filho, avalia o romance Controle, de Natalia Borges Polesso, publicado pela Companhia das Letras em 2019. E Jacques Fux analisa o livro Aranhas, de Carlos Henrique Schroeder, lançado pela Record em 2020.

Boa leitura.

João Claudio Arendt (UFMS/ANPOLL) joaoarendt@gmail.com

Mariana Simoni (FU-Berlin) maiasimoni@gmail.com

Vitor Cei (UFES) vitorcei@gmail.com

Editores ad hoc 